\title{
Environmental impact on the Mediterranean Spanish coast produced by the latest process of urban developments
}

\author{
J. L. Miralles i Garcia ${ }^{1}$, S. Díaz Aguirre ${ }^{2}$ \& V. J. Altur Grau ${ }^{1}$ \\ ${ }^{I}$ UDR F. Eiximenis, Dpt of Urbanisme, \\ Polytechnic University of Valencia, Spain \\ ${ }^{2}$ Pinar del Rio University, Cuba
}

\begin{abstract}
The extraordinary urban development that has occurred in Spain in the period of 1997-2007 allows us to analyze directly the generated environmental problems. In this period, between 300,000 and 900,000 houses were built in Spain each year and many of them were built on the Mediterranean coast. In many areas of new urban development, houses are unsold because there is no market and many areas are completely urbanized but not built on. So this reality is a great laboratory where we can directly check the environmental consequences of unjustified urban developments. There is legislation for the prevention of the environmental impacts of urbanization in Spain. This legislation has failed to avoid unnecessary urban development although it has produced clear environmental impacts. The F. Eiximenis research group analyzed select cases on the Valencian coast (between Sagunto and Cullera) for assessing the environmental effects of these urban developments, particularly concerning the transformation of the soil's environmental value, the consumption of resources and the emissions. The land transformation has been analysed by CORINE data, digital images and direct observation. This paper explains the situation produced and the main findings of the research.

Keywords: urban development, urban planning, natural resource management, environmental impact and urban governance.
\end{abstract}




\section{Introduction}

The latest real estate growth cycle started in Spain from about 1997 as noted by Miralles i Garcia [1], after the previous regressive cycle (1991-1996). This new growth cycle has been generated by a financial speculative process and not in response to meet objective requirements or objective demands of the housing market. Much of the housing has been built on the Spanish coast and particularly on the Mediterranean coast.

The growth cycle stopped in 2007. It is estimated that the stock of houses for sale is about 1.5 million of which about 700,000 houses are newly built. This stock has remained the same since late 2011. That is, despite the sharp decline in housing production from a peak of 900,000 dwellings in 2008 to at least 100,000 homes in 2011, the housing stock to sell has maintained or even increased slightly.

The Valencia coast is a paradigm of this process as it is of Spanish regions where the economy is specialized in the construction sector. At present we can observe and analyze the environmental and economic consequences that this process has produced.

The F. Eiximenis research group conducted an investigation in 2011 in the vicinity of the city of Valencia to document some cases of urban expansion produced in this process.

The vast majority of urban expansion processes that have occurred in Spain in this period were made in a planned manner complying with current legislation (only exceptional cases have been illegal or irregular).

So this is a historically novel situation in which the extraordinary urban development generated produced a very severe economic crisis. It is a clear case of unsustainable development. This analysis is keen to know the process and to generate the conditions necessary to avoid the risk of repeating the disaster that is occurring now.

\section{The landscape transformation on artificial land in the Valencia region}

You can see the general situation in Spain in De Carvalho and Jiménez Herrero [2]. To understand the magnitude of the problem in the Valencia Region a set of meaningful data is provided on the transformation of rural land into urban land according to the CORINE [3] data.

The available data on land use described the changes that took place up to 2006. Since this year can be identified as the last before the start of the housing crisis (2007), the data range is considered significant to analyze the soil resource consumption as a result of the urbanization process which started in Valencia in 1997.

As seen in the data collected in Table 1, the process of urbanization has led to an increase in the percentage of using artificial surfaces (urban land, infrastructure, industrial land, ...) at the expense of a decrease in rural land use. Identifying the patterns of distribution of land uses that were artificial and rustic 
derived from existing urbanization in Valencia, has been analyzed using the GIS tool, mapping information available in the database of CORINE Land Cover data, concerning changes in land use which occurred during the periods 1990 2000 and 2000-2006.

Table 1: $\quad$ Effects of urbanization on land use in the Valencian region. Rural land and artificial surfaces, 1991 [4] and 2005 [5].

\begin{tabular}{|c|c|c|c|c|}
\cline { 2 - 5 } \multicolumn{1}{c|}{} & \multicolumn{2}{c|}{1991} & \multicolumn{2}{c|}{2005} \\
\cline { 2 - 5 } \multicolumn{1}{c|}{} & Hectares & $\%$ & Hectares & $\%$ \\
\hline Artificial surfaces & $91.081,66$ & 3,94 & $160.197,00$ & 6,89 \\
\hline Non artificial surfaces & $2.237 .401,30$ & 96,06 & $2.162 .447,47$ & 93,1 \\
\hline
\end{tabular}

For analysis, the territory of Valencia has been divided into three zones: coastal, pre-coastal and interior. The coastal zone includes the 60 municipalities next to the sea. The pre-coastal zone has been delimited from the definition of a buffer zone around the coastal municipalities of $20 \mathrm{~km}$. The other municipalities have been included in the interior zones.

Table 2: $\quad$ Territorial distribution of land using artificial soil processed from 1990 to 2006 in the province of Castellon.

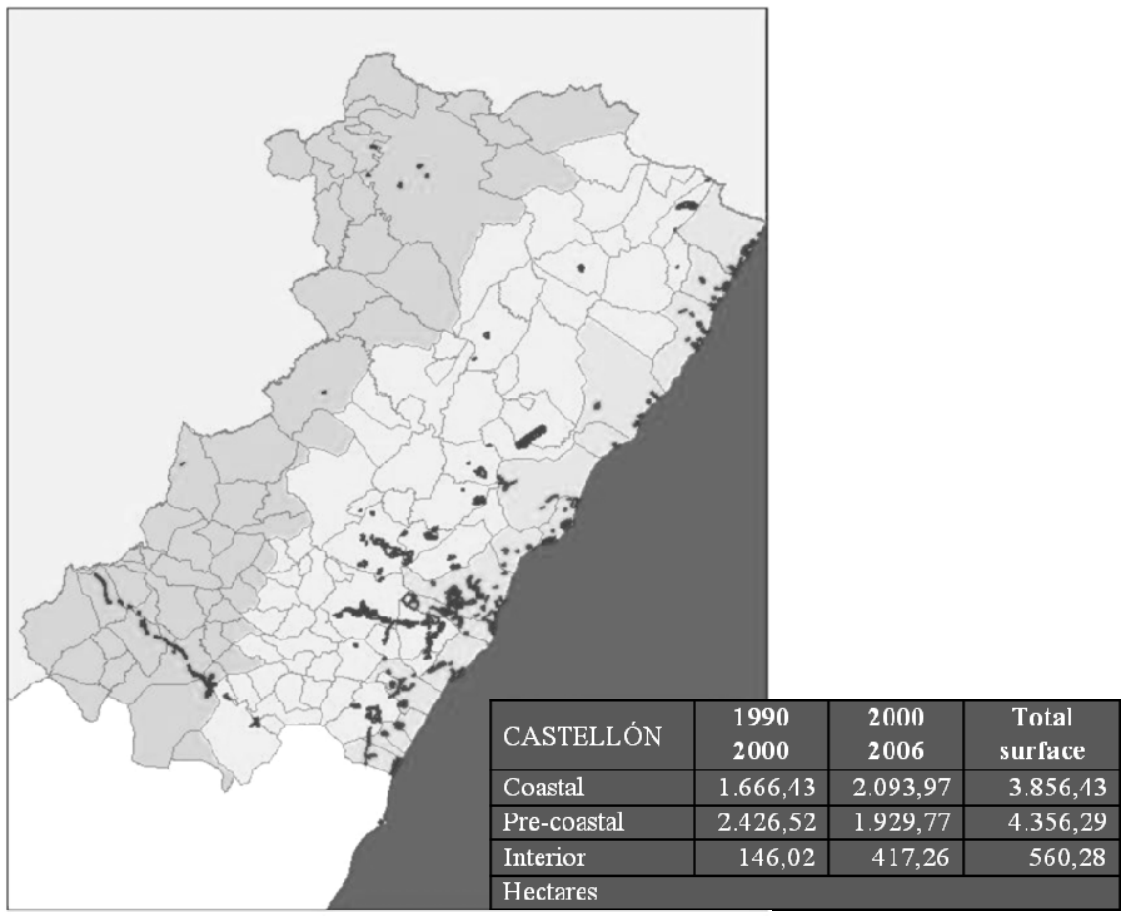


To identify changes in land uses, level 1 of the nomenclature database of Corine Land Cover has been considered: (1. Artificial surfaces; 2. Agricultural areas; 3. Forest vegetation zones and open spaces; 4. Wetlands; 5. Water surfaces).

The spatial distribution of the Valencian Community (provinces of Castellón, Valencia and Alicante) and the total floor area (hectares) where there was a change to artificial use from 1990 until 2006 can be seen in Tables 2-4.

Table 3: Territorial distribution of land using artificial soil processed from 1990 to 2006 in the province of Valencia.

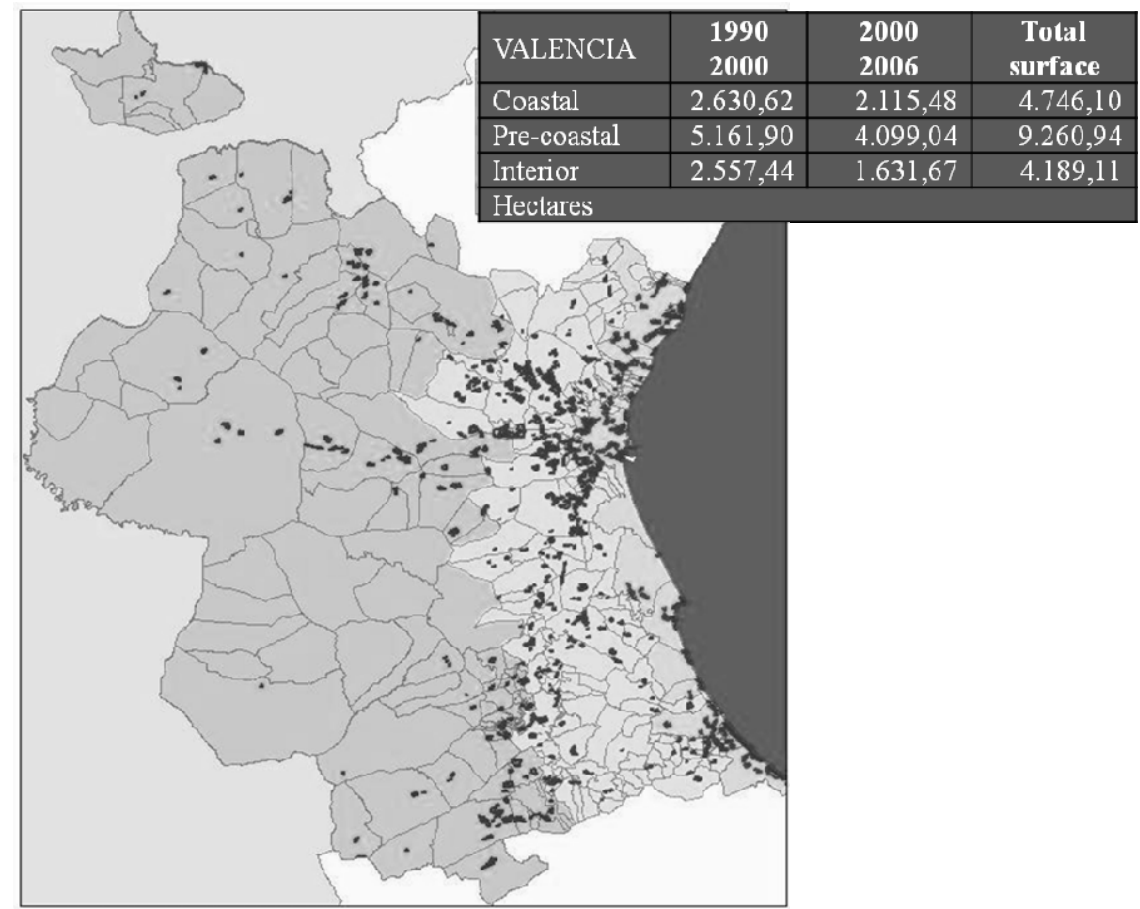

On the coast of Alicante, the rate of surface artificiality represents approximately $60 \%$ of total change on the coastal zone of the Valencia Region. In contrast, in the pre-coastal zone of Valencia the use changes to surface artificial doubles the changes in the coastal zone. Finally, note that the uses change to artificial surface in the interior zone of Castellón represents $8 \%$ of the total registered in this zone of the Valencia Region.

Therefore, there has been an intense process of urbanization in the Valencia Region concentrated in the coastal and pre-coastal zones. 
Table 4: Territorial distribution of land using artificial soil processed from 1990 to 2006 in the province of Alicante.

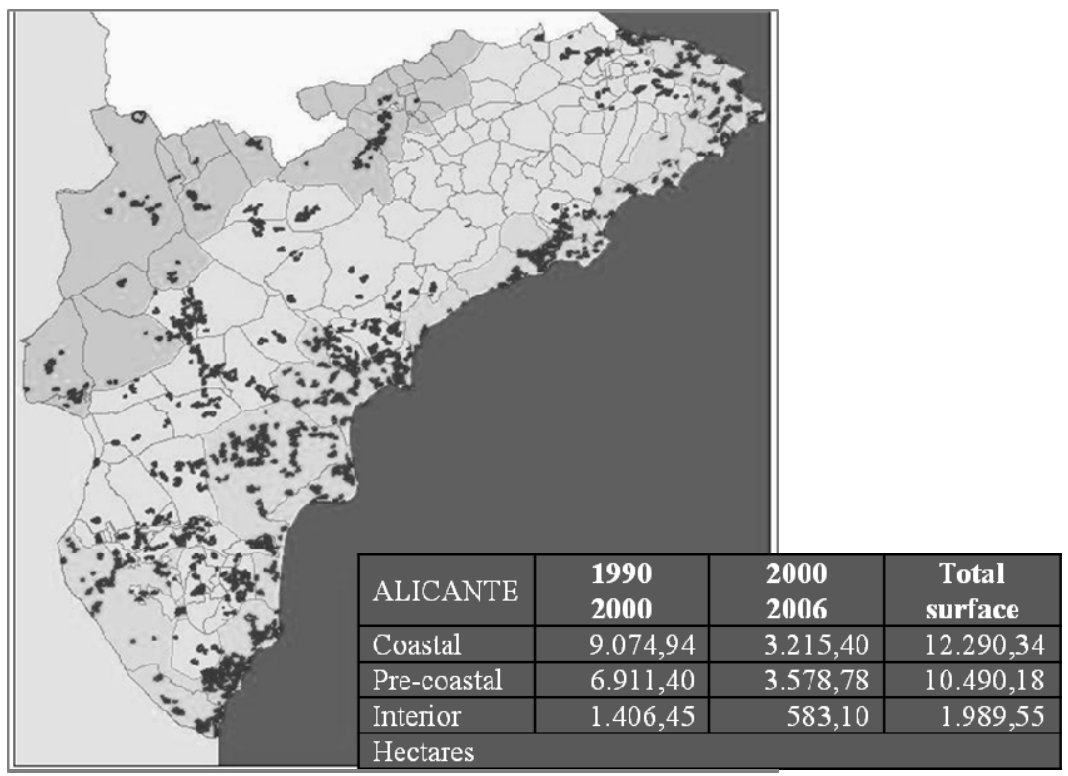

\section{Paradigmatic cases: Sagunto and El Puig}

The processes of land transformation that have occurred have been mixed and produced by a variety of causes. At present there is no study of the Spanish coast or the coast of Valencia with the systematization of all the transformation processes that have occurred. There are also no data, particularly in the case of urban developments, about the situation of the degree of development of these processes (administrative processing, approval, execution of infrastructure works and build construction).

However, we know that there are many cases of land which has been urbanized but not built. We have therefore focused our attention on two cases of this type. These are cases of urbanization generated by the sales expectation created by the constant increase in housing prices. Recall that during the real estate cycle expansion (Miralles [6]) housing prices were increasing by about $15 \%$ each year and this situation generated an artificial housing demand by the expectation of profit from the sale of housing built.

This dynamic continued until 2007. Just at this time the process of urban development in the two case studies began: SUNP sectors I and II of the municipality of Sagunto and North Round Sector of the municipality of El Puig. Both real estate developments are located north of the province of Valencia comprising an area of about $10 \mathrm{~km}$.

The sectors SUNP-I and SUNP-II of Sagunto are two sectors for integrated urban development under the general plan of urban development of Sagunto 
approved in 1988 (i.e., many years before the expansive real estate cycle). Initially it was planned as developable land not programmed, i.e., as a reserve for future development. The basic data such urban areas can be seen in Table 5 .

Table 5: $\quad$ Basic data sectors SUNP I and II of the municipality of Sagunto.

\begin{tabular}{|c|c|c|c|c|}
\hline SECTOR & $\begin{array}{c}\text { SURFACE } \\
\text { (ha) }\end{array}$ & HOUSES/HA & $\begin{array}{c}\text { HOUSES } \\
\text { NUMBER }\end{array}$ & INHABITANTS \\
\hline I & 38,9 & 75 & 2918 & 8753 \\
\hline II & 43,9 & 75 & 3293 & 9878 \\
\hline
\end{tabular}

Conversely, the general plan of Sagunto of 1988 foresaw an urban development for 17,985 housing growth in a population of 53,955 inhabitants (plus the expected increase in already developed urban land). In 1988, Sagunto had a total population of 56.551 ; in 2010 , the number had grown to 66,259 inhabitants.

In the municipality of El Puig, a general urban plan was approved in 1999. The plan of urban development provides for an increase from 1,595 homes to 4,147 inhabitants. The population of El Puig had in 1999 a total of about 7117 inhabitants. The general plan of 1999 was designed for a maximum of 20,000 inhabitants including normal and the beach resort town with temporary

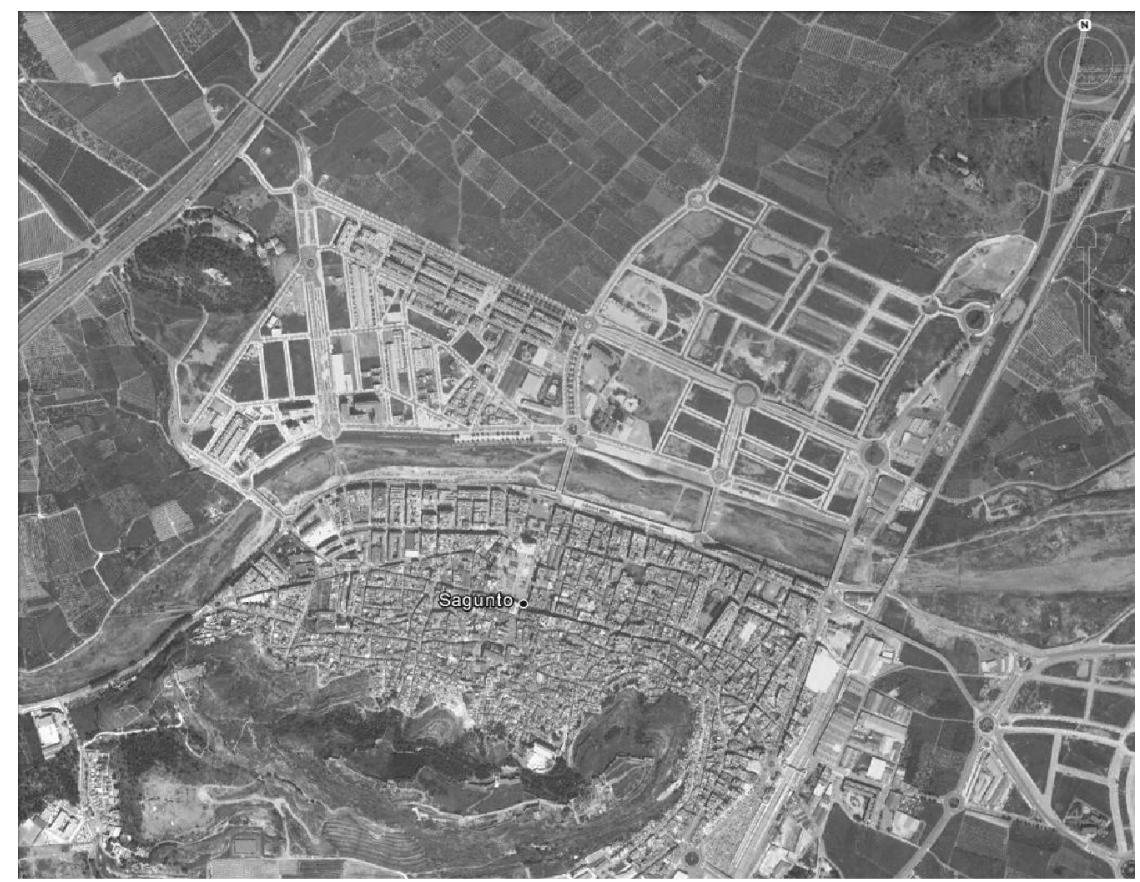

Figure 1: $\quad$ Google image of sectors SUNP I and II of Sagunto (28/04/2010). 
occupation in the summer term or vacation. In 2009 the municipality of El Puig had 8,670 inhabitants.

However, in 2006, the municipality of El Puig approved the development of a new residential land area not covered by the general plan: sector C-17 Round Nord. This sector provides for another 1117 homes for an additional 2900 inhabitants.

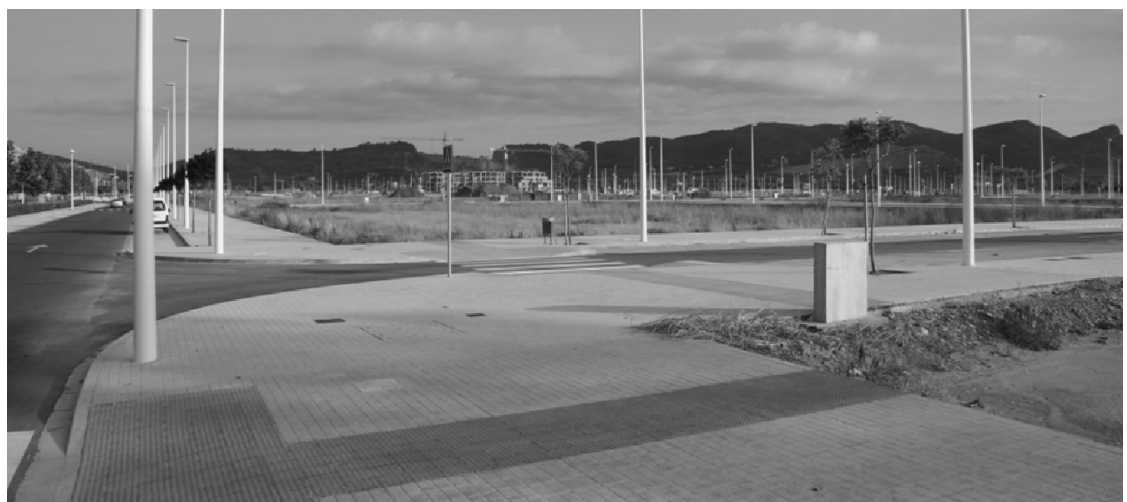

Figure 2: State of the sectors SUNP I and II of Sagunto in summer 2011, urbanized but not built

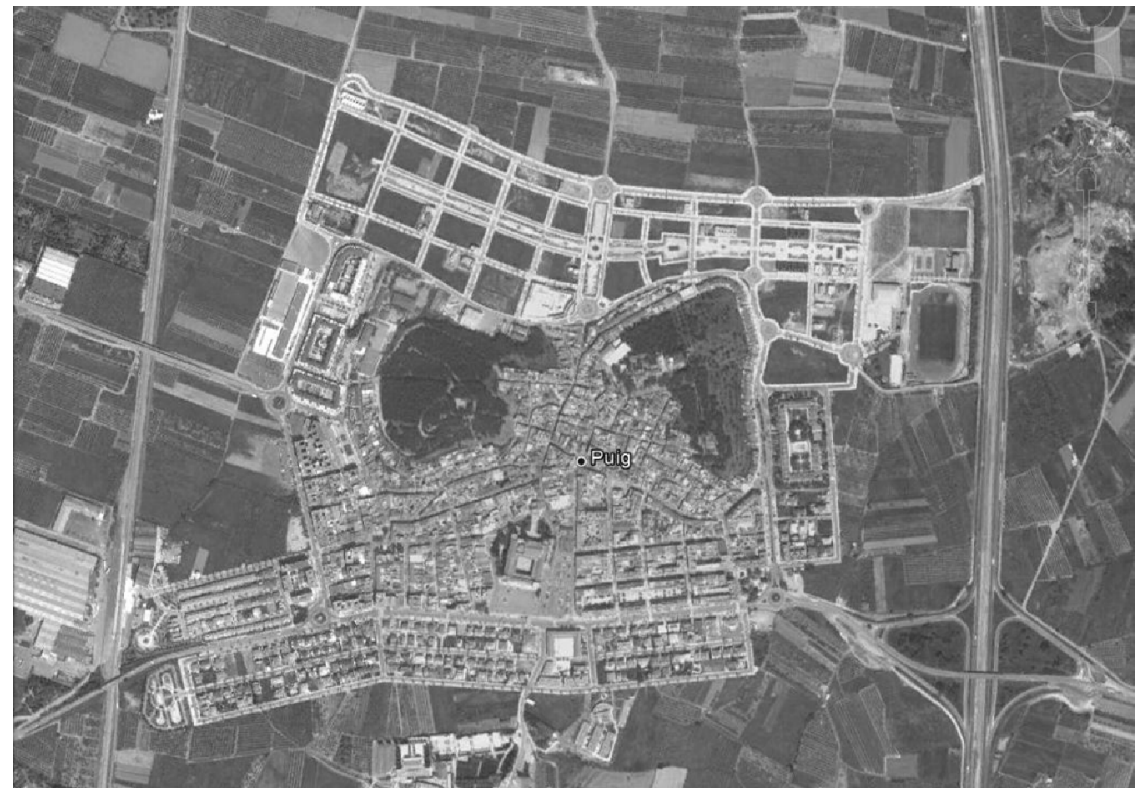

Figure 3: Google image of sectors Nord round of El Puig (28/04/2010). 
In the pictures you can see the zones with development works already completed in 2010 but almost without buildings. In 2012, the sectors remained without building. Investment in the case of El Puig is about $6 \mathrm{M} €$. In the case of Sagunto, investment is about $30 \mathrm{M} €$.

According to the Valencian urban management system, the local government approves the public interest of the urban development process and of selecting a developer agent (usually private) which funded the work and charges the costs to landowners. The land owners can pay with a part of the land of his property, so it is necessary to value this land. In this expansive real estate cycle, this valuation of land became very high according to zones: up to $150 €$ per square meter of land. Therefore, all stakeholders were in favour of urban development processes based on the expectation of the final sales price of houses.

Financial institutions, with trend analysis statistics evolution of prices paid to both home buyers and developers without requiring back guarantees. They covered their risks with the value of houses in a scenario of constant annual price rise of around $15 \%$.

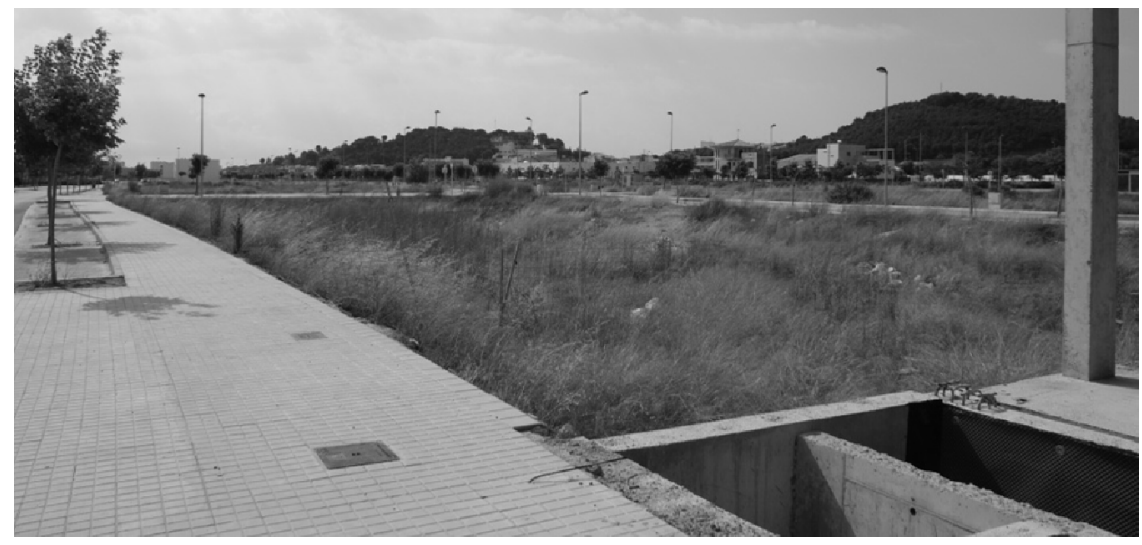

Figure 4: State of the sector Nord round of El Puig in summer 2011, urbanized but not built.

\section{Environmental consequences}

The environmental consequences on the one hand refer to the location and on the other to resource consumption and waste emission.

Regarding the location, all urban development means virtually irreversible transformation of the land. That is, the previously existing rural land has been destroyed and cannot be recovered. It is therefore an irreversible impact. Specifically, in our case studies there was agricultural use that was gone and the possibility of returning to such use was also lost. 
Regarding resource consumption, the urban development generates its mortgage. So, to make urban development and execution infrastructures work, the provision of water and electricity was needed as well as the areas of equipment necessary for the new population. But with the development works already executed, it is unknown if residential buildings will be built and, assuming they are built, it is not known when. So you have to maintain reserves of water and electricity for supply in anticipation of some future time if finally the zone is built. That is, we have mortgaged a consumption of resources that no longer can be devoted to other uses.

Another concern is the issue of wastewater and solid waste collection. Appropriate services have had to design or reserve water treatment capacity of the wastewater treatment plant and transportation of solid waste. Again, we have prepared facilities for services where it is unknown if or when they will be needed. That is, we have mortgaged the capabilities of emission treatment facilities.

The role of environmental impact studies is another important issue. The two case studies of urban development have had a favourable environmental impact assessment. In the case of Sagunto, an environmental impact assessment was made in 1988 for the general urban plan. This EIA considered the environmental impacts as correctable and would not affect protected areas. It was considered that urban development is associated with economic progress and this progress justifies the environmental impact produced. It was not provided for a situation of urbanization without building.

In the case of El Puig, the modification of the general plan for development of the new sector also had its environmental impact assessment done by the same criteria.

\section{Economic consequences}

The economic consequences are very important. On the one hand, financial institutions have normally paid the agent developer to implement the development works. The development agent collects these costs from landowners who normally pay with soil. If the agent developer cannot pay the bank with money, he can pay with the soil obtained or with constructed homes for sale. So the developer agent pays his debt by land assets and houses. But the houses can only be sold if the price drops significantly with consequent loss. And the land is not sold because there is no market, that is, because nobody wants to buy land to build in a situation of total excess supply of housing.

You can also say that this form has been invested in assets but not in productive economic activity. So when the construction sector is stopped, it generates a high unemployment rate without alternative work because, for lack of investment, there is little economic activity in other sectors of the economy.

Furthermore, on the other hand, municipalities must maintain the infrastructure already executed without having the revenue from the projected population to reside in the area. This situation creates an expense that the municipalities cannot afford or that must be paid by the rest of the population. 


\section{Conclusions}

Analysis of these cases allows the following conclusions:

- The land market to build has failed the function to optimize the use of economic resources in order to assign the best uses in the best locations. In the case studies, agricultural areas have been irreversibly transformed.

- Both the planning and environmental impact assessment identified as urban development and economic progress but they have not considered the situation of speculative urban development which produces urbanized areas which are not built on.

- The unbuilt on urbanized areas create an irreversible land transformation and a mortgage of resource consumption (water and electricity) and waste treatment capacity (wastewater and solid waste).

- The unbuilt on urbanized areas create an expensive cost of infrastructure maintenance to municipalities without increasing their income.

- Investment in the real estate sector negatively affected investment in productive economic activity.

- To know the magnitude of the process and make an accurate diagnosis on the Spanish or Valencian coast, is necessary to analyze and systematize all the processes of urban development on the coast.

\section{References}

[1] Miralles i Garcia, J.L. Real estate crisis and sustainability in Spain. Proc of the Sustainable Development and Planning V, eds C.A. Brebbia \& E. Beriatos, WIT Press: Southampton, pp. 123-133, 2011.

[2] De Carvalho, C. y Jiménez Herrero, L.M. Artificialización del suelo y sostenibilidad en las Costas. Indicadores del Observatorio de Sostenibilidad en España. Online. http://sostenibilidad.fongdcam.org/2011/03/20 /artificializacion-del-suelo-y-sostenibilidad-en-las-costas/

[3] Data base CORINE LAND COVER: changes 1990-2000 and changes 2000-2006. European Environment Agency. Online. http://www.eea.europa.eu/publications/COR0-landcover

[4] COPUT, El uso del suelo en la Comunidad Valenciana (Documento III del Avance del PDU - Territori; 6): València, 1995.

[5] Segmentación territorial basada en el proyecto SIOSE (Sistema de Información de Ocupación del Suelo en España). Estadísticias y mapas por provincias. 2005. Online http://www.cma.gva.es/web/indice.aspx? $\underline{\text { nodo }=63320 \& \text { idioma }=\mathrm{C}}$

[6] Miralles i Garcia, J.L. Sustainability regulations in urban planning: the experience of the Autonomous Community of Valencia (Spain). Proc of the $4^{\text {th }}$ Int. Conf. on Sustainable Development and Planning, eds. C.A. Brebbia, M. Neophytou, E. Beriatos, I. Ioannou \& A.G. Kungolos, WIT Press: Southampton, pp. 3-12, 2009. 
- The land market to build has failed the function to optimize the use of economic resources in order to assign the best uses in the best locations. In the case studies, agricultural areas have been irreversibly transformed.

- Both the planning and environmental impact assessment identified as urban development and economic progress but they have not considered the situation of speculative urban development which produces urbanized areas which are not built on.

- The unbuilt on urbanized areas create an irreversible land transformation and a mortgage of resource consumption (water and electricity) and waste treatment capacity (wastewater and solid waste).

- The unbuilt on urbanized areas create an expensive cost of infrastructure maintenance to municipalities without increasing their income.

- Investment in the real estate sector negatively affected investment in productive economic activity.

- To know the magnitude of the process and make an accurate diagnosis on the Spanish or Valencian coast, is necessary to analyze and systematize all the processes of urban development on the coast.

\section{References}

[1] Miralles i Garcia, J.L. Real estate crisis and sustainability in Spain. Proc of the Sustainable Development and Planning $V$, eds C.A. Brebbia \& E. Beriatos, WIT Press: Southampton, pp. 123-133, 2011.

[2] De Carvalho, C. y Jiménez Herrero, L.M. Artificialización del suelo y sostenibilidad en las Costas. Indicadores del Observatorio de Sostenibilidad en España. Online. http://sostenibilidad.fongdcam.org/2011/03/20 /artificializacion-del-suelo-y-sostenibilidad-en-las-costas/

[3] Data base CORINE LAND COVER: changes 1990-2000 and changes 2000-2006. European Environment Agency. Online. http://www.eea.europa.eu/publications/COR0-landcover

[4] COPUT, El uso del suelo en la Comunidad Valenciana (Documento III del Avance del PDU - Territori; 6): València, 1995.

[5] Segmentación territorial basada en el proyecto SIOSE (Sistema de Información de Ocupación del Suelo en España). Estadísticias y mapas por provincias. 2005. Online http://www.cma.gva.es/web/indice.aspx? $\underline{\text { nodo }}=63320 \&$ idioma $=\mathrm{C}$

[6] Miralles i Garcia, J.L. Sustainability regulations in urban planning: the experience of the Autonomous Community of Valencia (Spain). Proc of the $4^{\text {th }}$ Int. Conf. on Sustainable Development and Planning, eds. C.A. Brebbia, M. Neophytou, E. Beriatos, I. Ioannou \& A.G. Kungolos, WIT Press: Southampton, pp. 3-12, 2009. 